\title{
Effect of $\mathrm{NaCl}$ on leaf $\mathrm{H}^{+}$-ATPase and the relevance to salt tolerance in two contrasting poplar species
}

\author{
Xiuying Ma $\cdot$ Lin Deng $\cdot$ Jinke Li $\cdot$ Xiaoyang Zhou $\cdot$ Niya Li $\cdot$ \\ Decai Zhang • Yanjun Lu • Ruigang Wang · Jian Sun · Cunfu Lu • \\ Xiaojiang Zheng $\cdot$ Eberhard Fritz $\cdot$ Aloys Hüttermann $\cdot$ Shaoliang Chen
}

Received: 21 March 2009/Revised: 18 February 2010/Accepted: 24 February 2010/Published online: 12 March 2010

(C) The Author(s) 2010. This article is published with open access at Springerlink.com

\begin{abstract}
During a 30-day period of increasing salinity, we examined the effects of $\mathrm{NaCl}$ on leaf $\mathrm{H}^{+}$-ATPase and salinity tolerance in 1-year-old plants of Populus euphratica Oliv. (salt resistant) and P. popularis 35-44 (P. popularis) (salt sensitive). Electron probe $\mathrm{X}$-ray microanalysis of leaf mesophyll revealed that $P$. euphratica had a higher ability to retain lower $\mathrm{NaCl}$ concentrations in the cytoplasm, as compared to $P$. popularis. The sustained activity of $\mathrm{H}^{+}$pumps (by cytochemical staining) in salinised $P$. euphratica suggests a role in energising salt transport through the plasma membrane (PM) and tonoplast. Saltinduced alterations of leaf respiration, ATP content and expression of $\mathrm{PM} \mathrm{H}^{+}$-ATPase were compared between the two species. Results show that $P$. euphratica retained a constant respiratory rate, ATP production and protein
\end{abstract}

Communicated by H. Rennenberg.

X. Ma, L. Deng, J. Li and X. Zhou contributed equally to this work as first authors.

X. Ma - L. Deng $\cdot$ J. Li - X. Zhou - N. Li - D. Zhang - Y. Lu

R. Wang $\cdot$ J. Sun $\cdot$ C. Lu $\cdot$ S. Chen $(\bowtie)$

National Engineering Laboratory for Tree Breeding,

College of Biological Sciences and Technology,

Beijing Forestry University, Box 162, Beijing 100083,

People's Republic of China

e-mail: Lschen@bjfu.edu.cn

\section{Zheng $\cdot$ S. Chen}

Key Laboratory of Biological Resources Protection and Utilization in Hubei Province,

Hubei University for Nationalities, Enshi 445000,

People's Republic of China

E. Fritz · A. Hüttermann

Forest Botany and Tree Physiology, Büsgen Institute,

Georg-August-University of Göttingen,

Büsgenweg 2, 37077 Göttingen, Germany abundance of PM $\mathrm{H}^{+}$-ATPase (by Western blotting) in salt-stressed plants. P. euphratica was able to maintain a comparatively high capacity of ATP hydrolysis and $\mathrm{H}^{+}$ pumping during prolonged salt exposure. By contrast, the activity and expression of PM $\mathrm{H}^{+}$-ATPase were markedly decreased in $P$. popularis leaves in response to salt stress. Furthermore, NaCl-stressed $P$. popularis plants showed a marked decline of respiration (70\%) and ATP production $(66 \%)$ on day 30 . We conclude that the inability of $P$. popularis to transport salt to the apoplast and vacuole was partly due to the decreased activity of $\mathrm{H}^{+}$pumps. As a consequence, cytosolic ion concentrations were observed to be comparatively high for an extended period of time, so that cell metabolism, in particular respiration, was disrupted in $P$. popularis leaves.

Keywords ATPase $\cdot \mathrm{NaCl} \cdot$ Populus euphratica . Populus popularis $\cdot$ Respiratory rate $\cdot$ Salt tolerance . Western blotting $\cdot$ X-ray microanalysis

\section{Introduction}

The ability to successfully sequester salt ions $\left(\mathrm{Na}^{+}\right.$and $\mathrm{Cl}^{-}$) is considered to be a key determinant of plant salt tolerance. Compartmentalising $\mathrm{Na}^{+}$and $\mathrm{Cl}^{-}$into vacuoles and extruding these salts to the apoplast are two main strategies to retain low concentrations of $\mathrm{Na}^{+}$and $\mathrm{Cl}^{-}$in the cytoplasm (Hasegawa et al. 2000; Blumwald et al. 2000; Zhu 2001, 2003). Ottow et al. (2005a) showed a drastic accumulation of $\mathrm{Na}^{+}$in the apoplast relative to the protoplast in succulent Populus euphratica leaves. Similarly, we found that more $\mathrm{Na}^{+}$and $\mathrm{Cl}^{-}$ions accumulated in the cortical walls of $P$. euphratica roots, as compared to the salt-sensitive poplar species (Chen et al. 2002, 2003). It is 
noteworthy that $P$. euphratica has a greater ability to sequester salt ions, especially $\mathrm{Cl}^{-}$in root cortical vacuoles (Chen et al. 2002, 2003). The effective salt compartmentation in $P$. euphratica roots (including salt exclusion and vacuolar salt sequestration) is suggested to make a contribution to the restriction of ion loading into the root xylem during radial transport, and thus limits subsequent axial transport (Chen et al. 2002, 2003).

Salt compartmentation in vacuoles is partly dependent on active transport of salt ions across the tonoplast via $\mathrm{Na}^{+} / \mathrm{H}^{+}$ antiporter systems (Blumwald and Poole 1985; Garbarino and Dupont 1988) or $\mathrm{H}^{+}$-coupled $\mathrm{Cl}^{-}$antiport (Schumaker and Sze 1987). It is suggested that the greater capacity for $\mathrm{Na}^{+}$exclusion in $P$. euphratica is the result of an active $\mathrm{Na}^{+}$ extrusion via $\mathrm{Na}^{+} / \mathrm{H}^{+}$antiporters across the PM (Sun et al. 2009). PeNhaD1 and PeSOS1 likely function as $\mathrm{PM} \mathrm{Na}^{+} /$ $\mathrm{H}^{+}$antiporters in P. euphratica (Ottow et al. 2005b; Lü et al. 2007; Wu et al. 2007; Sun et al. 2009). The transcript levels of PeNhaD1 and PeSOS1 were maintained constant in $P$. euphratica under saline conditions (Ottow et al. 2005b; Wu et al. 2007) but declined in a salt-sensitive genotype, P. canescens (PeNhaD1, Ottow et al. 2005b; PtSOS1, Escalante-Pérez et al. 2009). $\mathrm{H}^{+}$-ATPase pumps protons and maintains electrochemical $\mathrm{H}^{+}$gradients, thus promoting the secondary active $\mathrm{Na}^{+} / \mathrm{H}^{+}$antiport through the plasma membrane (PM) and tonoplast (Blumwald et al. 2000; Zhu 2003). It can be inferred that the regulation $\mathrm{H}^{+}$-ATPase activity represents an important cellular mechanism for salt tolerance. $\mathrm{H}^{+}$pumping activity of $\mathrm{H}^{+}$-ATPase in tonoplast vesicles, isolated from $P$. euphratica suspension cells, increased upon $\mathrm{NaCl}$ treatment (Ma et al. 2002). This is thought to be of benefit for energising the transport of salts into the vacuole. Shabala and Newman suggested the involvement of PM H${ }^{+}$-ATPase in $\mathrm{Na}^{+} / \mathrm{H}^{+}$antiport under $\mathrm{NaCl}$ stress (Shabala 2000; Shabala and Newman 2000). $\mathrm{Na}^{+}$movement across PM vesicles of $P$. tomentosa callus is highly dependent on $\mathrm{H}^{+}$-ATPase activity requiring ATP and $\mathrm{Mg}^{2+}$ (Yang et al. 2007a). Using the scanning ion-selective electrode technique (SIET), we found that the inhibitor of the $\mathrm{PM} \mathrm{H} \mathrm{H}^{+}$-ATPase, sodium orthovanadate, simultaneously decreased $\mathrm{Na}^{+}$efflux and $\mathrm{H}^{+}$influx along the root axis of long-term-stressed $P$. euphratica plants (Sun et al. 2009). Evidence by Western blotting proved that the expression of $\mathrm{PM} \mathrm{\textrm {H } ^ { + }}$-ATPase was up-regulated by $\mathrm{NaCl}$ stress in calluses and leaf tissues of $P$. euphratica (Yang et al. 2007b; Zhang et al. 2007). However, the localisation of $\mathrm{H}^{+}$-ATPases in tissue cells of $P$. euphratica and their response to salinity were not investigated.

In this study, we used cytochemical technique to investigate the effects of $\mathrm{NaCl}$ stress on the activity of $\mathrm{H}^{+}$-ATPase in a salt-tolerant species, $P$. euphratica and a salt-sensitive species, $P$. popularis. Western blotting was employed to assess the protein expression of PM $\mathrm{H}^{+}$-pumps during the period of salt treatment. The aim of this study is to assess the relevance of leaf $\mathrm{H}^{+}$-ATPases for salt tolerance of poplar plants. Moreover, we want to examine the effects of increasing and prolonged salt stress on leaf respiration, since $\mathrm{H}^{+}$-ATPase requires plenty of energy (ATP), delivered by mitochondrial respiration, to mediate salt exclusion from the cytosol.

\section{Materials and methods}

Plant materials

The salt-tolerant poplar species $P$. euphratica Oliv. ( $P$. euphratica, 1-year-old seedlings, obtained from the Xinjiang Uygur Autonomous Region of China) and saltsensitive species $P$. popularis 35-44 (P. popularis, 1-yearold hardwood cuttings, obtained from the nursery of Beijing Forestry University, BFU) were used in this study. In April (2007, 2008), P. euphratica and P. popularis plants were planted in individual pots containing $10 \mathrm{~L}$ of loam soil and sand (soil:sand $=1: 1, \mathrm{v} / \mathrm{v}$ ) and placed in a greenhouse of BFU. The plants in pots were irrigated 2-3 times per week, depending on the evaporative demand and received $1 \mathrm{~L}$ of full-strength Hoagland's nutrient solution every 2 weeks. Plants were raised 3 months prior to the initiation of salt treatment (in July). Fifty to sixty uniform plants for each species, which were about 50-80 cm high, were selected for the following experiment.

\section{Salt treatment}

Poplar plants were subjected to 30 days of increasing salinity, i.e. $1 \mathrm{~L}$ of $50,100,150$, and $200 \mathrm{mM} \mathrm{NaCl}$ in fullstrength Hoagland's nutrient solution was applied on day 1, day 8 , day 15 and day 22, respectively. Control plants were kept well-watered and weekly fertilized with no addition of $\mathrm{NaCl}$.

Leaf harvests and measurements

At each sampling time, destructive harvest of leaves for biochemical analyses were carried out for three independent replicates (plants) per treatment. Western blotting of the plasma membrane (PM) $\mathrm{H}^{+}$-ATPase was performed weekly. X-ray microanalysis and cytochemical staining of leaf cells were conducted on day 22 and 30. ATP content in leaves was measured at the end of experiment. Leaf respiratory rates were measured in non-destructive plants during the period of treatment (three individual plants were examined for each treatment). 
X-ray microanalysis

Energy-dispersive X-ray microanalysis was used to examine the salt distribution within cells. To stimulate the emission of characteristic X-rays from a specimen, a highenergy beam is focused into the sample being studied. The number and energy of the X-rays emitted from a specimen can be measured by an energy-dispersive spectrometer. In this study, leaves were sampled after 22 and 30 days of exposure to salt treatment for 3 independent replicates per treatment. Leaf sections, $2 \times 2 \mathrm{~mm}$, cut from upper mature leaves (leaf numbers $6-10$ from shoot apex) were divided to two groups: one group for subcellular element examination and another for cytochemical staining of $\mathrm{H}^{+}$-ATPase (see below). Sample preparations for X-ray microanalysis were followed as Fritz (1989) with modifications. In brief, leaf sections were immediately placed in isopentane which had been cooled with liquid nitrogen. Thereafter, sections were vacuum freeze-dried at $-106^{\circ} \mathrm{C}$ for 4 days. Following freeze-drying, the samples were allowed to equilibrate with room temperature for $24 \mathrm{~h}$ and then stored over silica gel until embedding in plastic. Freeze-dried samples (6-8 leaf sections sampled from each plant) were placed in vacuum-pressure chambers, infiltrated with diethyl ether for $24 \mathrm{~h}$ before infiltrating with plastic. The infiltration steps were 1:1 ether:plastic $(\mathrm{v} / \mathrm{v})$ for $24 \mathrm{~h}, 1: 2$ ether:plastic for $24 \mathrm{~h}, 1: 3$ ether:plastic for $24 \mathrm{~h}$, and finally $100 \%$ plastic $(24 \mathrm{~h}, \times 2)$. Following infiltration, samples were transferred to gelatine capsules and polymerized at $60^{\circ} \mathrm{C}$ for at least 7 days. After polymerization, leaves ( 3 samples for each plant) were sectioned into $1-\mu \mathrm{m}$ thick slices on a dry glass knife with an ultramicrotome, mounted on copper grids (mesh 50), coated with carbon and stored over silica gel until analysis.

The slices were examined with a HITACHI-H800 transmission electron microscope assembled with an EDAX-9100 energy-dispersive X-ray analyzer. The accelerating voltage was $150 \mathrm{keV}$ with the take-off angle of $25^{\circ}$. In the mesophyll cells, cell wall, vacuoles and cytoplasm were examined. For each compartment, 10-20 measurements were made at each section and the counting time was $60 \mathrm{~s}$. The data were expressed as counts per second (CPS) of an element peak after subtraction of the background.

\section{Cytochemical analysis of $\mathrm{H}^{+}$-ATPase}

For $\mathrm{H}^{+}$-ATPase activity analysis, sections were cut from the same leaves that were used for X-ray microanalysis. $\mathrm{Pb}\left(\mathrm{NO}_{3}\right)_{2}$ staining was used to indicate ATPase activity as described by Malone et al. (1977) and Jian et al. (2000) with some modifications. The histochemical localization of ATPase activity is based on the reaction of $\mathrm{Pb}^{2+}$ with the liberated free phosphate, which forms electron-dense insoluble precipitates $\mathrm{Pb}_{3}\left(\mathrm{PO}_{4}\right)_{2}$. The staining intensity indicates the hydrolysis activity of the ATPase. Leaf samples (12-16 sections for each plant) were fixed in a solution of $50 \mathrm{mM}$ cacodylate buffer $(\mathrm{pH} 7.2), 4 \%(\mathrm{v} / \mathrm{v})$ paraformaldehyde and $2.5 \%(\mathrm{v} / \mathrm{v})$ glutaraldehyde for $2 \mathrm{~h}$. Thereafter, tissues were washed in $50 \mathrm{mM}$ cacodylate buffer $(\mathrm{pH}$ $7.2)$ for $30 \mathrm{~min}(\times 4)$. Then the leaf samples $(6-8$ sections for each plant) were incubated for $3 \mathrm{~h}$ in a reaction mixture containing $50 \mathrm{mM}$ Tris-maleate buffer $(\mathrm{pH} 7.2), 2 \mathrm{mM}$ ATP, $5 \mathrm{mM} \mathrm{MgSO}_{4}$ and $3 \mathrm{mM} \mathrm{Pb}\left(\mathrm{NO}_{3}\right)_{2}$. For the blank control, tissues (6-8 sections for each plant) were incubated in the reaction mixture without ATP addition. After rinsing with $50 \mathrm{mM}$ Tris-maleate buffers $(\mathrm{pH} 7.2)(30 \mathrm{~min}, \times 2)$ and $50 \mathrm{mM}$ cacodylate buffer $(\mathrm{pH} 7.2)(30 \mathrm{~min}, \times 4)$, the samples were fixed overnight in $50 \mathrm{mM}$ cacodylate buffer (pH 7.2) containing $1 \% \mathrm{OsO}_{4}$ at room temperature. Finally, tissues were washed four times with redistilled water, dehydrated with acetone and embedded in Epon 812 resin. Embedded samples (three sections for each treatment) were sectioned into $0.02-\mu \mathrm{m}$-thick slices with an ultramicrotome and photographed with an electron microscope JEM 100 CX (JEOL, Tokyo, Japan).

Western blotting of the PM $\mathrm{H}^{+}$-ATPase

\section{Protein extraction}

Upper mature leaves (leaf numbers 6-10 from the shoot apex) were sampled weekly from control and salinised plants of the two species. Approximate $1 \mathrm{~g}$ tissue was homogenized in liquid nitrogen. This requires 8-10 leaves for $P$. euphratica and 1-2 leaves for $P$. popularis. At each sampling time, three individual plants were sampled for each treatment. The plant protease inhibitor, PVPP, was mixed with the ground tissue before the addition of $3 \mathrm{~mL}$ of pre-cooled extract containing $50 \mathrm{mM}$ pH 7.5 Tris-HCl, 2\% (w/v) SDS, $2 \mathrm{mM}$ EDTA, $5 \mathrm{mM}$ ascorbate, $14 \mathrm{mM} \beta$-mercaptoethanol, $1 \mathrm{mM}$ PMSF, $1 \mu \mathrm{g} \mathrm{L}^{-1}$ leupeptin, $1 \mu \mathrm{g} \mathrm{L}^{-1}$ pepstain, $1 \mu \mathrm{g} \mathrm{L}^{-1}$ aprotinin and $0.15 \%$ (w/v) PVPP. The filtrate was centrifuged at $12,000 \mathrm{~g}$ for $20 \mathrm{~min}$ at $4^{\circ} \mathrm{C}$ and supernatant was used for electrophoresis. The protein concentration of total extracts was determined with BSA as the standard according to Bradford (1976).

\section{SDS-PAGE}

A $60-\mu \mathrm{L}$ enzyme solution was mixed with $60 \mu \mathrm{L}$ SDSloading buffer containing $1 \mathrm{M}$ Tris- $\mathrm{HCl}(\mathrm{pH} 6.8), 25 \%$ (v/v) glycerol, 4\% (w/v) SDS, $0.01 \%(\mathrm{w} / \mathrm{v})$ bromocresol blue and $0.1 \%(\mathrm{v} / \mathrm{v}) \beta$-mercaptoethanol. The mixture was incubated in thermostatic water bath at $100^{\circ} \mathrm{C}$ for $5 \mathrm{~min}$, then centrifuged at $12,000 \mathrm{~g}$ for $5 \mathrm{~min}$ at $4^{\circ} \mathrm{C}$. The 
supernatant was used for SDS-PAGE separation (sodium dodecyl sulphate-polyacrylamide gel electrophoresis) (Laemmli 1970). A 50- $\mathrm{gg}$ protein was loaded onto a discontinuous SDS-PAGE (4\% stacking gel and $10 \%$ separating gel) and electrophoretic separation was performed with a mini electrophoresis system (Bio-Rad, Richmond California, USA). After the electrophoresis, one of the two identical gels was stained with Coomassie Brilliant Blue R-250 to check the protein of $\mathrm{PM} \mathrm{H^{+ }}$ ATPase. The stained gel was scanned by the Scanner UMAX Powerlook 2100XL.

\section{Western blot analysis}

Western blotting was conducted according to the method described by Pan (2005). In brief, immediately after electrophoresis, the polypeptides were electrophoretically transferred to a $0.45-\mu \mathrm{m}$ nitrocellulose membrane (Amersham Life Science) using a Transblot DYCZ-40D apparatus (Liuyi, Beijing, China). Transfer buffer contained $15.6 \mathrm{mM}$ Tris, $120 \mathrm{mM}$ Gly, and $20 \%$ (v/v) methanol. The constant flow was $100 \mathrm{~mA}$ at $4^{\circ} \mathrm{C}$ for $6 \mathrm{~h}$ during electrophoretic transfer. After this, the membrane was washed three times in TBS (Tris-buffered saline: $10 \mathrm{mM}$ Tris- $\mathrm{HCl}$ and $150 \mathrm{mM} \mathrm{NaCl}, \mathrm{pH} 7.5$ ), blocked overnight with $2 \%$ (w/v) bovine serum albumin (BSA) and $0.05 \%$ (v/v) Tween 20. The protein-transferred nitrocellulose membrane was incubated with monoclonal antibodies against Arabidopsis PM $\mathrm{H}^{+}$-ATPase (AHA3) that was previously diluted 10,000-fold with blocking medium containing $10 \mathrm{mM}$ Tris$\mathrm{HCl}(\mathrm{pH} \mathrm{7.5)}, 150 \mathrm{mM} \mathrm{NaCl}, 2 \%$ (w/v) BSA and $0.05 \%$ (v/v) Tween 20. The incubation system was gently shaken for $3 \mathrm{~h}$ at room temperature. After rinsing three times with TBS-T $_{1}[10 \mathrm{mM}$ Tris-HCl pH 7.5, $150 \mathrm{mM} \mathrm{NaCl}$ and $0.05 \%(\mathrm{v} / \mathrm{v})$ Tween 20], the membrane was incubated for $1 \mathrm{~h}$ at room temperature with a 1:800 (v/v) diluted secondary antibody [alkaline phosphatase-conjugated goat anti-rabbit $\mathrm{IgG}$ antibodies $(\mathrm{H}+\mathrm{L})$, Bio-Rad] in $\mathrm{TBS}_{2} \mathrm{~T}_{2}$ containing $50 \mathrm{mM}$ Tris- $\mathrm{HCl} \mathrm{pH} 7.5,150 \mathrm{mM} \mathrm{NaCl}$ and $0.05 \%(\mathrm{v} / \mathrm{v})$ Tween 20 and $1 \%(\mathrm{w} / \mathrm{v})$ BSA. Then the membrane was washed three times with $\mathrm{TBS}_{2} \mathrm{~T}_{2}$. Finally, the alkaline phosphatase reaction was developed in dark by 5-bromo-4-chloro-3-indolyl phosphate and nitroblue tetrazolium (BCIP-NBT) alkaline phosphatase substrate (B-5655, Sigma-Aldrich). The coloration reaction appeared after about $10 \mathrm{~min}$ and was terminated by redistilled water. The images of $\mathrm{PM} \mathrm{H}^{+}$-ATPases immuno-reactive bands of the membrane were captured using the Gel Imaging System (Bio-Rad). The image density of each band relative to that of the control was estimated using the software Gel-pro Analyzer (version 4.0, Media Cybernetics, Inc. Bethesda, MD, USA).
Leaf ATP content

\section{ATP extraction}

Leaves in upper shoot (leaf numbers 6-10 from the shoot apex) were sampled from control and $\mathrm{NaCl}$-treated plants at the end of experiment. Three independent replicates were harvested for each treatment. Samples were immediately frozen in liquid nitrogen and stored at $-80^{\circ} \mathrm{C}$ freezer for ATP content assay. ATP extraction was based on the method of Wang and Gu (1986) but with some modifications. Approximate $0.5 \mathrm{~g}$ leaves were immersed into $10 \mathrm{~mL}$ of heat buffer solution $(20 \mathrm{mM} \mathrm{pH} 7.8$ Tris buffer solution, $100^{\circ} \mathrm{C}$ ) and incubated for $10 \mathrm{~min}$ at $100^{\circ} \mathrm{C}$. Subsequently, the samples were cooled down on ice and the supernatant was used for ATP measurement. The average recovery ratio of leaf ATP was ca $92 \%$. We found that the recovery ratio of $P$. euphratica (89-91\%) was lower than $P$. popularis (93-95\%).

\section{ATP assay}

The luciferin/luciferase method to measure the ATP concentration was applied according to Wang (1985). A $0.2 \mathrm{~mL}$ of ATP extract was mixed with $0.8 \mathrm{~mL}$ luciferin/ luciferase solution (Shanghai Institute of Plant Physiology, Chinese Academy of Sciences) in the test tubule and then placed in the reaction darkroom of spectrophotometer. Luminescence was measured with the F-4500 FL Spectrophotometer (Hitachi, Japan) at $25^{\circ} \mathrm{C}$ and the luminiferous peak was recorded (relative light units, RLU). Fluorescence measurement conditions were as follows: $120 \mathrm{~s}$ of time scan, $0 \mathrm{~nm}$ excitation wavelength and $525 \mathrm{~nm}$ emission wavelength (excitation and emission slit was $2.5 \mathrm{~nm}$ ). Concentrations of ATP in leaves were calculated according to the ATP standard curve.

\section{ATP standard curve}

To establish the ATP standard curve, a series of ATP concentrations were prepared (in luciferase buffer solution): $5 \times 10^{-12}, 5 \times 10^{-11}, 5 \times 10^{-10}$ and $5 \times 10^{-9} \mathrm{M}$. A $0.2 \mathrm{~mL}$ of ATP standard solution was sucked into the test tubule and reacted with $0.8 \mathrm{~mL}$ luciferin/luciferase. For the blank background, $0.2 \mathrm{~mL}$ of luciferase buffer, instead of ATP solution, was put into the tubule and the maximum RLU was recorded. In our study, the ATP versus RLU curve yielded a regression coefficient of 0.99 . (There are two key points for ATP measurements: (1) luciferase-luciferin solution and ATP standard solutions should be prepared just before being used, and (2) luciferin/luciferase solution should be placed in thermostatic 
water bath of $25^{\circ} \mathrm{C}$ to retain its activity during the measuring time.)

\section{Leaf respiratory rate}

The portable infra-red gas analysis system (CIRAS-2 portable IRGA system, PP-systems, Amesbury, MA, USA) was adopted for the assay of leaf respiratory rate according to Turcsányi et al. (2000). The $\mathrm{CO}_{2}$ exchange of upper mature leaves (leaf numbers 6-10 from shoot apex, dark adapted) was determined at regular time during the period of 30 days of salt treatment. Three individual plants per treatment were examined at each measuring time (three leaves were measured for each plant) and the temperature in the greenhouse was $25-29^{\circ} \mathrm{C}$. Leaves were dark adapted for $1 \mathrm{~h}$ prior to the gas exchange measurement. Leaf respiratory rate was examined at $29-31^{\circ} \mathrm{C}$ and the measured area in leaf cuvette was $1.7 \mathrm{~cm}^{2}$.

\section{Data analysis}

The experimental data of X-ray microanalysis, ATP content and leaf respiratory rate were subjected to ANOVA and significant differences between means were determined by Duncan's multiple-range test. Unless otherwise stated, differences were considered statistically significant when $P<0.05$. Representative images illustrating the activity and protein content of leaf ATPase were given.

\section{Results}

Sodium and chloride compartmentation in mesophyll cells

Under no-salt conditions, $\mathrm{Na}^{+}$was not detected in mesophyll compartments of both species (Fig. 1a, c, e). The fraction of $\mathrm{Na}^{+}$in the measured cell compartments increased with the duration of $\mathrm{NaCl}$ stress in the two poplars, but a more pronounced effect was usually observed in P. popularis (Fig. 1a, c, e). $\mathrm{Na}^{+}$concentrations in the cell wall, cytoplasm and vacuole were typically lower in $P$. euphratica than in $P$. popularis after 22 days of salt treatment (Fig. 1a, c, e). The same trend was observed on day 30 with the exception of vacuole, in which more $\mathrm{Na}^{+}$ions were accumulated in $P$. euphratica, as compared to $P$. popularis (Fig. 1a, c, e). It is worth noting that $\mathrm{NaCl}$ treated $P$. euphratica showed a greater capacity to control $\mathrm{Na}^{+}$in the cytosol, i.e. $\mathrm{Na}^{+}$fraction in the cytoplasm was
Fig. 1 Effects of $\mathrm{NaCl}$ on $\mathrm{Na}^{+}$ and $\mathrm{Cl}^{-}$concentrations (CPS counts per seconds) in leaf mesophyll compartments of $P$. euphratica (salt tolerant) and $P$. popularis (salt sensitive). Leaves in upper shoot (leaf number 6-10 from shoot apex) were sampled and vacuum freeze-dried, infiltrated in ether and polymerised with plastic.

Samples were cut into

$1-\mu \mathrm{m}$-thick sections for X-ray microanalysis. Probe measurements were made on cell wall, cytoplasm and vacuole in mesophyll cells. Ten to 20 measurements were taken from each leaf section. Each column is the mean of three plants and bars represent the standard error of the mean. Columns labelled with different letters are significantly different at $P<0.05$

lower than its concentration in the wall and vacuole over the observation periods (Fig. 1a, c, e).

The $\mathrm{Cl}^{-}$compartmentation in mesophyll cells resembled a trend similar to $\mathrm{Na}^{+}$during the period of salt stress (Fig. 1b, d, f). On day 22, salt-induced increase of $\mathrm{Cl}^{-}$ in all measured cell compartments remained lower in $P$. euphratica than in P. popularis (Fig. 1b, d, f). However, $\mathrm{Cl}^{-}$in the wall and vacuole of $P$. euphratica markedly increased in the following 8 days, reaching a level similar to that of $P$. popularis on day 30 (Fig. 1b, f). Compared with $P$. popularis, salinised $P$. euphratica was effective to retain a lower $\mathrm{Cl}^{-}$in the cytoplasm (Fig. 1d).
$\mathrm{H}^{+}$-ATPase activity

$\mathrm{Pb}\left(\mathrm{NO}_{3}\right)_{2}$ staining for $\mathrm{H}^{+}$-ATPase is based on the reaction product of $\mathrm{Pb}^{2+}$ with liberated free phosphate and the staining intensity represents the hydrolysis activity of the $\mathrm{H}^{+}$-ATPase. As shown in Fig. 2a, b, i, j, staining was absent when the substrate, ATP, was not added to incubating solution. $\mathrm{Pb}\left(\mathrm{NO}_{3}\right)_{2}$ staining was seen in control cells of the two species, but there were marked differences in the response to salinity (Fig. 2c-h, k-p). On day 22 , the activity of $\mathrm{H}^{+}$-ATPase in plasma membrane (PM) and tonoplast increased evidently in salinised
Fig. 2 Representative TEM images showing cytochemical analysis of $\mathrm{H}^{+}$-ATPase activity in leaf cells of $P$. euphratica (salt tolerant) and P. popularis (salt sensitive). For $\mathrm{H}^{+}$-ATPase activity analysis, sections were cut from the same leaves that were used for X-ray microanalysis. The staining intensity of $\mathrm{Pb}\left(\mathrm{NO}_{3}\right)_{2}$ represents the hydrolysis activity of the $\mathrm{H}^{+}$-ATPase. Blank control $(\mathbf{a}, \mathbf{b}, \mathbf{i}, \mathbf{j})$ (ATP was absent in the reaction solution); Control (c, d, k, l); $\mathrm{NaCl}$ (day 22) (e, f, m, n), $\mathrm{NaCl}$ (day 30) $(\mathbf{g}, \mathbf{h}, \mathbf{o}, \mathbf{p})$. $V$ vacuole, $N$ nucleus, $C$ chloroplast, $T$ tonoplast, $P M$ plasma membrane, Cyt cytosol. Arrows indicate the reaction product of $\mathrm{Pb}^{2+}$ with liberated free phosphate

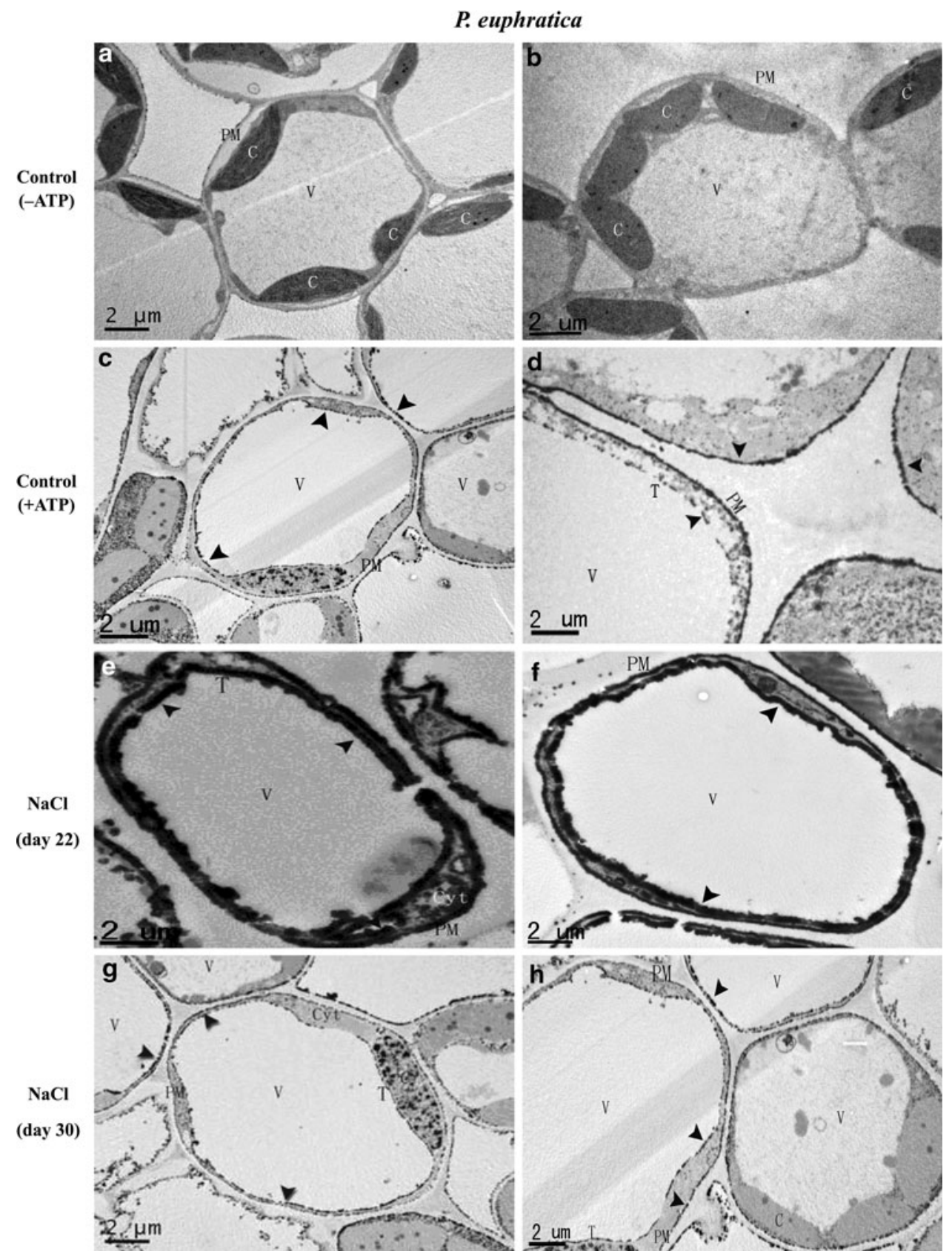


Fig. 2 continued



$P$. euphratica, whereas there were no corresponding changes in $P$. popularis (Fig. 2e, f, $m, n$ ). The same trend was observed on day 30 , although $P$. euphratica displayed a less intense staining as compared to day 22 (Fig. 2g, h, o, p).

Western blot analysis of $\mathrm{PM} \mathrm{H}^{+}$-ATPase

Using the antibody against Arabidopsis $\mathrm{PM} \mathrm{H}^{+}$-ATPase, the content of the expressed protein was examined weekly during the period of salt treatment. There are species differences in the response to salinity between the two poplars although a low protein abundance (i.e. the immuno-reactive bands) was found on the membrane (Fig. 3). The expression of $\mathrm{PM} \mathrm{H}^{+}$-ATPase in $P$. popularis leaves increased on the first week of stress, but markedly declined in the following 3 weeks (Fig. 3). Unlike $P$. popularis, $\mathrm{PM} \mathrm{H} \mathrm{H}^{+}$-ATPase content in $P$. euphratica increased upon the salt stress and remained at a constant level over the observation periods, although the level of the expressed protein in control plants was lower than $P$. popularis (Fig. 3). 

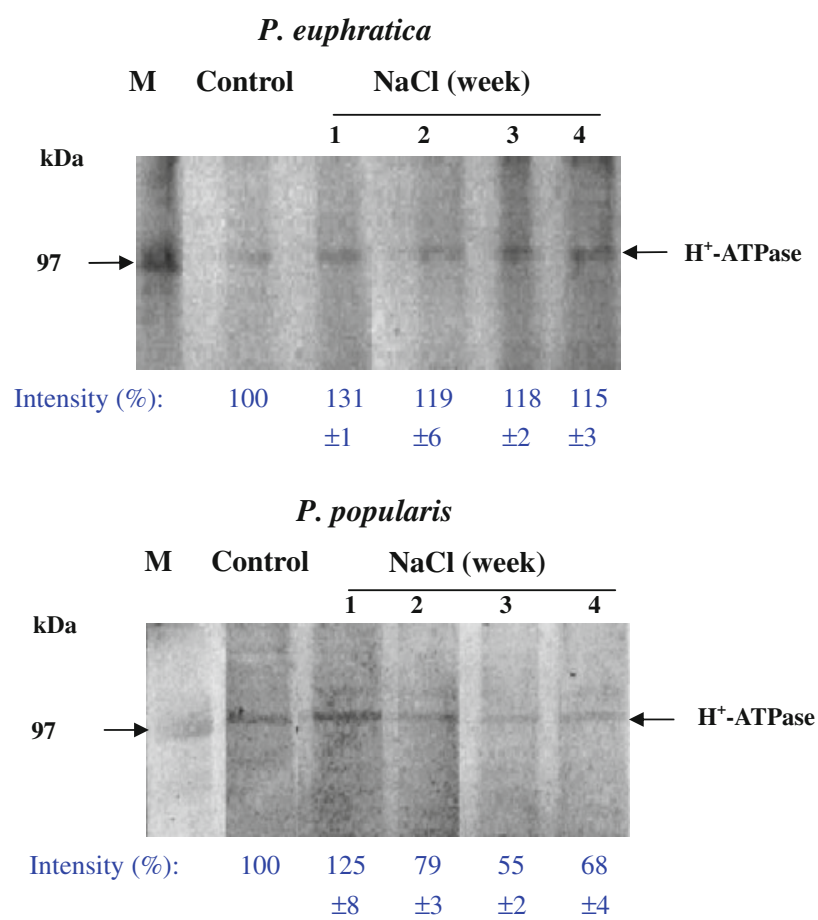

Fig. 3 Representative images showing Western blotting of plasma membrane $\mathrm{H}^{+}$-ATPase in leaves of $P$. euphratica (salt tolerant) and $P$. popularis (salt sensitive). $M$ standard markers for molecular mass, Control control plants, lane $1 \mathrm{NaCl}$ (1 week), lane $2 \mathrm{NaCl}$ (2 weeks), lane $3 \mathrm{NaCl}$ (3 weeks), lane $4 \mathrm{NaCl}$ (4 weeks). A total of $50 \mu \mathrm{g}$ of protein was loaded per lane. After SDS-PAGE and Western blotting, immunodecoration was performed with monoclonal primary antibody against Arabidopsis PM $\mathrm{H}^{+}$-ATPase (AHA3) and with secondary antibody [alkaline phosphatase-conjugated goat anti-rabbit IgG antibodies $(\mathrm{H}+\mathrm{L})]$. The image density of each band was expressed as \% of the control and each value $( \pm \mathrm{SD})$ is the mean of three individual plants

\section{ATP content of leaves}

As shown in Fig. 4, control plants of $P$. popularis typically have a higher ATP content than P. euphratica. Salinity reduced ATP content in leaves of the two species, but the inhibitory effect of $\mathrm{NaCl}$ on ATP level was more pronounced in the salt-sensitive species, P. popularis (Fig. 4). Until the end of the experiment, ATP content decreased by $66 \%$ in stressed $P$. popularis but the decline was $14 \%$ in P. euphratica (Fig. 4).

\section{Leaf respiratory rate}

The respiratory rate $(\mathrm{Rn})$ in $P$. popularis leaves tends to decrease with increasing duration of salt stress and reached the minimum on day 30 , at which time a $70 \%$ decline was found (Fig. 5). In contrast to P. popularis, $\mathrm{Rn}$ in $\mathrm{NaCl}-$ treated $P$. euphratica leaves markedly increased after 7 days of salt treatment, and remained $25-35 \%$ higher than control plants during the following days of treatment (Fig. 5).



Fig. 4 Effects of $\mathrm{NaCl}$ on ATP content in leaves of $P$. euphratica (salt tolerant) and $P$. popularis (salt sensitive). Leaves in upper shoot (leaf number 6-10 from shoot apex) were sampled from control and salt-stressed plants. Each column is the mean of three plants and bars represent the standard error of the mean. Columns labelled with different letters are significantly different at $P<0.05$

\section{Discussion}

Leaf $\mathrm{NaCl}$ compartmentation and salinity tolerance

X-ray microanalysis shows that the salt-resistant species P. euphratica generally exhibits lower $\mathrm{Na}^{+}$and $\mathrm{Cl}^{-}$concentrations in all subcellular compartments as compared to the salt-sensitive $P$. popularis, after 22 days of salt treatment (Fig. 1). This implies that salt uptake into the roots, or subsequent transport to the leaves was controlled more efficiently in the salt-tolerant species (Chen et al. 2002, 2003). Moreover, long-term stressed $P$. euphratica had a higher ability to retain a low concentration of $\mathrm{Na}^{+}$and $\mathrm{Cl}^{-}$ in the cytoplasm, which may result from the vacuolar salt compartmentation and salt extrusion (Fig. 1). Vacuolar fractions of $\mathrm{Na}^{+}$and $\mathrm{Cl}^{-}$in $P$. euphratica markedly increased coincident with the increasing salinity (Fig. 1). It is also evident that the rate of salt uptake into the vacuole (and the apoplast) between day 22 and 30 was higher in $P$. euphratica as compared to P. popularis (Fig. 1). In the latter species, full storage capacity of salt ions in the apoplast and vacuole was apparently achieved already on day 22, whereas $P$. euphratica continued to exclude salt ions form the cytosol beyond this time point (Fig. 1). It is noteworthy that the rise of $\mathrm{Na}^{+}$and $\mathrm{Cl}^{-}$in P. euphratica was lower in the cytoplasm than in the cell wall after an extended period of salt treatment (Fig. 1). Similarly, Ottow et al. (2005a) found that a large amount of $\mathrm{Na}^{+}$accumulated in the leaf apoplast of $P$. euphratica. The preferential accumulation of $\mathrm{Na}^{+}$and $\mathrm{Cl}^{-}$in cell wall relative to the cytoplasm implies the active extrusion of salts from the cytosol, in addition to ion sequestration in the vacuole. This 


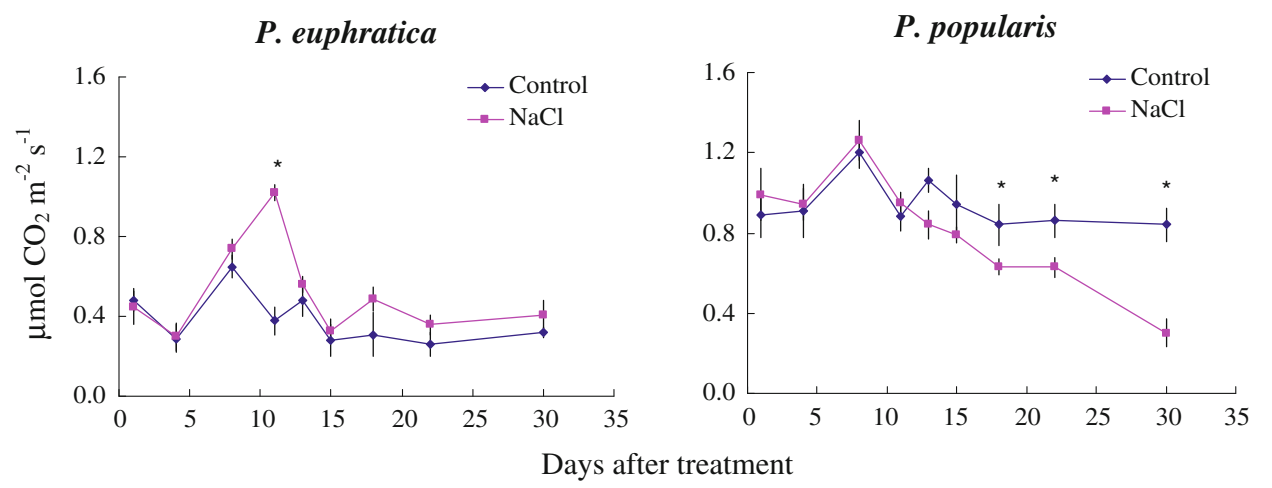

Fig. 5 Effects of $\mathrm{NaCl}$ on respiratory rates $(\mathrm{Rn})$ in leaves of $P$. euphratica (salt tolerant) and $P$. popularis (salt sensitive). Gas exchange measurements were conduced on leaves in upper shoot (leaf number 6-10 from shoot apex). Each point is the mean of three plants (three leaves were examined for each plant) and bars represent the standard error of the mean. An asterisk denotes a significant difference at $P<0.05$ between control and $\mathrm{NaCl}$ treatments

PM, $\mathrm{H}^{+}$-ATPase has been claimed to be involved in PM $\mathrm{Na}^{+} / \mathrm{H}^{+}$antiport by means of a non-invasive ion flux technique [microelectrode ion flux estimation (MIFE)] (Shabala 2000; Shabala and Newman 2000). Our pharmacological experiments at tissue and cellular levels showed that the $\mathrm{Na}^{+} / \mathrm{H}^{+}$exchange in long-term-stressed $P$. euphratica was associated with the PM H${ }^{+}$-ATPase (Sun et al. 2009). Therefore, the $\mathrm{Na}^{+}$extrusion through $\mathrm{Na}^{+} / \mathrm{H}^{+}$antiporters in P. euphratica, e.g. PeNhaD1 (Ottow et al. 2005b), PeSOS (Wu et al. 2007), is thought to be activated by the $\mathrm{H}^{+}$ gradients generated by the $\mathrm{PM} \mathrm{H}^{+}$-ATPase (Blumwald et al. 2000; Kerkeb et al. 2001; Zhu 2003; Yamaguchi and Blumwald 2005). Accordingly, P. popularis was unable to sequester $\mathrm{Na}^{+}$and $\mathrm{Cl}^{-}$into vacuoles or to extrude these salts to the apoplast, presumably due to the lower $\mathrm{H}^{+}$pumping activity.

Western blot analysis shows that the protein abundance of $\mathrm{PM} \mathrm{H}^{+}$-ATPase in P. euphratica was not decreased after exposure to a longer-term salt stress (Fig. 3). This is consistent with cytochemical analysis of $\mathrm{H}^{+}$-ATPase (Fig. 2), indicating that the sustained activity of $\mathrm{H}^{+}$pump is partly the result of protein abundance. Similarly, the expression of $\mathrm{PM} \mathrm{H}^{+}$-ATPase was found to be up-regulated by $\mathrm{NaCl}$ stress in calluses and leaves of P. euphratica (Yang et al. 2007b; Zhang et al. 2007). The abundance of $\mathrm{H}^{+}$-ATPase protein is presumably associated with the level of gene expression. Using Affymetrix poplar gene chips, microarray data show that $P$. euphratica retains a typically higher transcript abundance of the genes encoding $\mathrm{H}^{+}$ATPases, as compared to P. popularis (Ding et al. 2010). Accordingly, the two salt-tolerant Italian $P$. alba clones, 14P11 and 2AS11, up-regulated V-ATPase genes at intermediate salinity (14 days) (Beritognolo et al. 2007). In the present study, the immuno-reactive band of the membrane was not clear, which was mainly due to (1) the lower abundance of $\mathrm{H}^{+}$-ATPase in the PM, and/or (2) the lower 
affinity of $P$. euphratica $\mathrm{H}^{+}$-ATPase with the antibody AHA3 (Arabidopsis PM $\mathrm{H}^{+}$-ATPase), which originated from a herbaceous species.

We conclude that $P$. euphratica was able to retain the activity of $\mathrm{H}^{+}$-ATPase during the period of salt exposure. As a consequence, cytosolic ion concentration remained comparatively low (for a longer time), so that cell metabolism was not disrupted; in particular respiration (as observed for $P$. popularis). This enables $P$. euphratica cells to provide plenty of energy (ATP), delivered by mitochondrial respiration for $\mathrm{H}^{+}$pumps to continuously exclude salt from the cytosol.

Acknowledgments The research was supported jointly by the HITECH Research and Development Program of China (863 Program, 2006AA10Z131), the National Natural Science Foundation of China (30430430, 30872005), Foundation for the Supervisors of Beijing Excellent Doctoral Dissertation (YB20081002201), Foundation for the Authors of National Excellent Doctoral Dissertation of PR China (200152), the Teaching and Research Award Program for Outstanding Young Teachers in Higher Education Institution of Ministry of Education (MOE), Ministry of Education (PRC) (2002-323), Key project of MOE (2009-84) and the Natural Science Foundation of Hubei province (2007ABB003). We thank Dr. Ramón Serrano Salom (Institute of Plant Molecular and Cellular Biology, Technical University of Valencia, Spain) for kindly providing the antibody against Arabidopsis PM $\mathrm{H}^{+}$-ATPase. Dr. Xiangning Jiang is sincerely acknowledged for assistance to operate F-4500 fluorescence spectrophotometer. We thank Ms Hui Zhang for TEM samples sectioning and the offer for the use of the electron microscope by PLIE (the Platform of Large Instruments and Equipment) at the Beijing Forestry University.

Open Access This article is distributed under the terms of the Creative Commons Attribution Noncommercial License which permits any noncommercial use, distribution, and reproduction in any medium, provided the original author(s) and source are credited.

\section{References}

Beritognolo I, Piazzai M, Benucci S, Kuzminsky E, Sabatti M, Mugnozza GS, Muleo R (2007) Functional characterisation of three Italian Populus alba L. genotypes under salinity stress. Trees Struct Funct 21:465-477

Blumwald E, Poole RJ (1985) $\mathrm{Na}^{+} / \mathrm{H}^{+}$antiporter in isolated tonoplast vesicles form storage tissue of Beta vulgaris. Plant Physiol 78:163-167

Blumwald E, Aharon GS, Apse MP (2000) Sodium transport in plant cells. Biochim Biophys Acta 1465:140-151

Bradford MM (1976) A rapid and sensitive method for the quantitation of microgram quantities of protein utilizing the principle of protein-dye binding. Anal Biochem 72:248-254

Chen SL, Li JK, Fritz E, Wang SS, Hüttermann A (2002) Sodium and chloride distribution in roots and transport in three poplar genotypes under increasing $\mathrm{NaCl}$ stress. For Ecol Manag 168:217-230

Chen S, Li J, Wang S, Hüttermann A, Altman A (2003) Effects of $\mathrm{NaCl}$ on shoot growth, transpiration, ion compartmentation and transport in regenerated plants of Populus euphratica and Populus tomentosa. Can J For Res 33:967-975
Ding M, Hou P, Shen X, Wang M, Deng S, Sun J, Xiao F, Wang R, Zhou X, Lu C, Zhang D, Zheng X, Hu Z, Chen S (2010) Saltinduced expression of genes related to $\mathrm{Na}^{+} / \mathrm{K}^{+}$and $\mathrm{ROS}$ homeostasis in leaves of salt-resistant and salt-sensitive poplar species. Plant Mol Biol. doi:10.1007/s11103-010-9612-9

Escalante-Pérez M, Lautner S, Nehls U, Selle A, Teuber M, Schnitzler JP, Teichmann T, Fayyaz P, Hartung W, Polle A, Fromm J, Hedrich R, Ache P (2009) Salt stress affects xylem differentiation of grey poplar (Populus $\times$ canescens). Planta 229:299-309

Fritz E (1989) X-ray microanalysis of diffusible elements in plant cells after freeze-drying, pressure infiltration with ether and embedding in plastic. Scanning Microsc 3:517-526

Garbarino J, Dupont FM (1988) $\mathrm{NaCl}$ induces a $\mathrm{Na}^{+} / \mathrm{H}^{+}$antiport in tonoplast vesicles from barley roots. Plant Physiol 86:231236

Gévaudant F, Duby G, von Stedingk E, Zhao R, Morsomme P, Boutry M (2007) Expression of a constitutively activated plasma membrane $\mathrm{H}^{+}$-ATPase. Plant Physiol 144:1763-1776

Hasegawa PM, Bressan RA, Zhu JK, Bohnert HJ (2000) Plant cellular and molecular responses to high salinity. Ann Rev Plant Physiol Plant Mol Biol 51:463-499

Jian L-C, Sun L-H, Li J-H, Wang H, Sun D-L, Li PH (2000) $\mathrm{Ca}^{2+}$ homeostasis differs between plant species with different coldtolerance at $4^{\circ} \mathrm{C}$ chilling. Acta Bot Sin 42:358-366

Kerkeb L, Donaire JP, Venema K, Rodriguez-Rosales MP (2001) Tolerance to $\mathrm{NaCl}$ induces changes in plasma membrane lipid composition, fluidity and $\mathrm{H}^{+}$-ATPase of tomato calli. Physiol Plant 113:217-224

Laemmli UK (1970) Cleavage of structural proteins during the assembly of the head of bacteriophage T4. Nature 227:680-685

Lü PP, Hu J, Chen SL, Shen X, Yin WL, Chen YH, Sun YR, Hu ZM (2007) Function of the putative $\mathrm{Na}^{+} / \mathrm{H}^{+}$antiporter gene PeNhaD1 from salt-resistant Populus euphratica Oliv. J Plant Physiol Mol Biol 33:173-178 (in Chinese with English abstract)

Ma T, Liu Q, Li Z, Zhang X (2002) Tonoplast $\mathrm{H}^{+}$-ATPase in response to salt stress in Populus euphratica cell suspensions. Plant Sci 163:499-505

Malone CP, Burke JJ, Hanson JB (1977) Histochemical evidence for the occurrence of oligomycin-sensitive plasmalemma ATPase in corn roots. Plant Physiol 60:916-922

Ottow EA, Polle A, Brosché M, Kangasjärvi J, Dibrov P, Zörb C, Teichmann T (2005a) Molecular characterization of PeNhaD1: the first member of the $\mathrm{NhaD} \mathrm{Na}{ }^{+} / \mathrm{H}^{+}$antiporter family of plant origin. Plant Mol Biol 58:73-86

Ottow EA, Brinker M, Teichmann T, Fritz E, Kaiser W, Brosché M, Kangasjärvi J, Jiang X, Polle A (2005b) Populus euphratica displays apoplastic sodium accumulation, osmotic adjustment by decreases in calcium and soluble carbohydrates, and develops leaf succulence under salt stress. Plant Physiol 139:1762-1772

Pan W (2005) $\beta$-Catenin regulates myogenesis by relieving I-mfamediated suppression of myogenic regulatory factors in P19 cells. PNAS 102:17378-17383

Schumaker KS, Sze H (1987) Decrease of pH gradients in tonoplast vesicles by $\mathrm{NO}_{3}{ }^{-}$and $\mathrm{Cl}^{-}$: evidence for $\mathrm{H}^{+}$-coupled anion transport. Plant Physiol 83:490-496

Shabala S (2000) Ionic and osmotic components of salt stress specifically modulate net ion fluxes from bean leaf mesophyll. Plant Cell Environ 23:825-837

Shabala S, Newman IA (2000) Salinity effects on the activity of plasma membrane $\mathrm{H}^{+}$and $\mathrm{Ca}^{2+}$ transporters in bean leaf mesophyll: masking role of the cell wall. Ann Bot 85:681-686

Sun J, Chen S, Dai S, Wang R, Li N, Shen X, Zhou X, Lu C, Zheng X, $\mathrm{Hu}$ Z, Zhang Z, Song J, Xu X (2009) NaCl-induced alternations of cellular and tissue ion fluxes in roots of salt-resistant and saltsensitive poplar species. Plant Physiol 149:1141-1153 
Turcsányi E, Lyons T, Plöchl M, Barnes J (2000) Does ascorbate in the mesophyll cell walls form the first line of defence against ozone? Testing the concept using broad bean (Vicia faba L). J Exp Bot 51:901-910

Vitart V, Baxter I, Doerner P, Harper JF (2001) Evidence for a role in growth and salt resistance of a plasma membrane $\mathrm{H}^{+}$-ATPase in the root endodermis. Plant J 27:191-201

Wang W (1985) Determination of ATP by bio-luminescence. Experiment Manual of Plant Physiol, pp 115-117 (in Chinese)

Wang W, Gu J (1986) Comparison of the methods for extracting ATP from plant leaves. Plant Physiol Commun 5:54-55 (in Chinese with English abstract)

Wang R, Chen S, Deng L, Fritz E, Hüttermann A, Polle A (2007) Leaf photosynthesis, fluorescence response to salinity and the relevance to chloroplast salt compartmentation and anti-oxidative stress in two poplars. Trees Struct Funct 21:581-591

Wang R, Chen S, Zhou X, Shen X, Deng L, Zhu H, Shao J, Shi Y, Dai S, Fritz E, Hüttermann A, Polle A (2008) Ionic homeostasis and reactive oxygen species control in leaves and xylem sap of two poplars subjected to $\mathrm{NaCl}$ stress. Tree Physiol 28:947-957
Wu Y, Ding N, Zhao X, Zhao M, Chang Z, Liu J, Zhang L (2007) Molecular characterization of PeSOS1: the putative $\mathrm{Na}^{+} / \mathrm{H}^{+}$ antiporter of Populus euphratica. Plant Mol Biol 65:1-11

Yamaguchi T, Blumwald E (2005) Developing salt-tolerant crop plants: challenges and opportunities. Trends Plant Sci 10:615620

Yang YQ, Hu L, Chen X, Ottow EA, Polle A, Jiang X (2007a) A novel method to quantify $\mathrm{H}^{+}$-ATPase-dependent $\mathrm{Na}^{+}$transport across plasma membrane vesicles. Biochim Biophys Acta 1768:2078-2088

Yang YL, Zhang F, Zhao M, An L, Zhang L, Chen N (2007b) Properties of plasma membrane $\mathrm{H}^{+}$-ATPase in salt-treated Populus euphratica callus. Plant Cell Rep 26:229-235

Zhang F, Wang Y, Yang YL, Wu H, Wang D, Liu JQ (2007) Involvement of hydrogen peroxide and nitric oxide in salt resistance in the calluses from Populus euphratica. Plant Cell Environ 30:775-785

Zhu J-K (2001) Plant salt tolerance. Trends Plant Sci 6:66-71

Zhu J (2003) Regulation of ion homeostasis under salt stress. Curr Opin Plant Biol 6:1-5 